
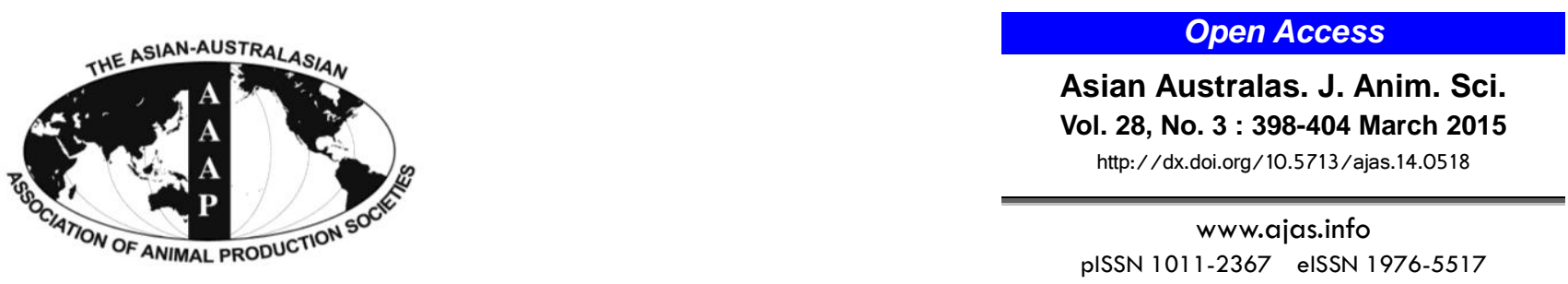

\title{
Meat Quality of Crossbred Porkers without the Gene RYR1 Depending on Slaughter Weight
}

\author{
Grażyna Czyżak-Runowska, Janusz Wojtczak, Andrzej Łyczyński, Jacek Wójtowski*, \\ Maria Markiewicz-Kęszycka ${ }^{1}$, Daniel Stanisławski ${ }^{2}$, and Marek Babicz ${ }^{3}$ \\ Department of Small Mammalian Breeding and Raw Materials of Animal Origin,
}

Faculty of Animal Breeding and Biology, Poznań University of Life Sciences, Suchy Las 62-002, Poland

\begin{abstract}
The first aim of the study was to compare selected meat quality parameters in porkers without the gene $R Y R I^{T}$ (ryanodine receptor gene). These were porkers slaughtered at 100 to $115 \mathrm{~kg}$ and 116 to $130 \mathrm{~kg}$ live weight. The second aim of the study was to determine the occurrence frequency of standard-quality meat (red, firm, nonexudative [RFN]) and the occurence frequency of defective meat (pale, soft, exudative [PSE] and acid, soft, exudative [ASE]). The analysis was conducted on the longissimus lumborum muscle in 114 crossbred porkers. The porkers were a cross of Camborough 22 sows and boars from lines 337PIC (Pig Improvement Company), Norsvin Landrace and Pietrain. All of the animals were provided with identical environmental and nutritional conditions. The average weight of the slaughtered animals in the light and heavy groups was $110 \mathrm{~kg}$ and $122 \mathrm{~kg}$, respectively. Both groups had the $\mathrm{s}$ ame average post-slaughter meatiness (56.5\%). A statistical analysis of selected meat-quality parameters did not show any sign ificant differences between the weight groups. On the other hand, the classification based on carcass quality showed an occur ence frequency of defective meat in heavier crossbred porkers (116 to $130 \mathrm{~kg}$ ) that was three times higher than in those cross bred animals which weighed 100 to $115 \mathrm{~kg}$ when slaughtered. In porkers without the gene $R Y R I^{T}$, the defective meat types PSE and ASE occurred with a frequency of $17.54 \%$. (Key Words: Acid Meat, Crossbreds, PSE, $R Y R I^{T}$ Gene, Slaughter Weight)
\end{abstract}

\section{INTRODUCTION}

One of the unsettling problems faced by the Polish and European meat industries is the high share of pig carcasses with symptoms of wateriness (Pospiech et al., 1998; Fischer 2007). For this reason, it is necessary to look for ways of decreasing the watery meat in pig carcasses. The genetic improvement of animals and the optimisation of

\footnotetext{
* Corresponding Author: J. Wójtowski. Tel: +48-61-8125520, Fax: +48-61-8125520, E-mail: jacwojto@gmail.com

${ }^{1}$ School of Agriculture and Food Science, University College Dublin, Belfield, Dublin 4, Ireland.

${ }^{2}$ Computer Laboratory of Faculty of Animal Breeding and Biology, Poznań University of Life Sciences, Poznań 60-637, Poland.

3 Department of Pig Breeding and Production Technology, University of Life Sciences in Lublin, Lublin 20-950, Poland.

Submitted Jul. 12, 2014; Revised Sept. 10, 2014; Accepted Oct. 14, 2014
}

environmental factors must be taken into account when working to improve meat quality (Eblis et al., 1999; Monin et al., 1999; Rosenvold and Andersen, 2003; Migdał et al., 2004; Koćwin-Podsiadła et al., 2006; Łyczyński et al., 2006; Borzuta et al., 2010; van Arendonk, 2011). The reports in scientific publications, however, are citing more and more frequent cases of lowered meat quality in animals without the $R Y R I^{T}$ (ryanodine receptor gene) gene (Fàbrega et al., 2002; Kortz et al., 2004; Florowski et al., 2007). At the same time, many authors are reporting that an increase in the live weight of porkers may be one of the factors which improve the quality of meat as well as limit the defects related to wateriness (Martin et al., 1980; Lee and Choi, 1999; Beattie et al., 1999; Koćwin-Podsiadła et al., 2002; Przybylski et al., 2005; Zybert et al., 2005; Correa et al., 2006; Strzelecki et al., 2007). This view, though, has not been confirmed by all research studies done in this area (Pospiech et al., 1983; Cisneros et al., 1996; Leach et al., 
1996; Latorre et al., 2004; Barowicz et al., 2006).

The first aim of our study was to compare selected quality parameters for the meat of porkers without $R Y R I^{T}$ and slaughtered at 100 to $115 \mathrm{~kg}$ and 116 to $130 \mathrm{~kg}$ live weight. The second aim was to determine the occurrence frequency of standard-quality meat (red, firm, nonexudative [RFN]) and defective meat (pale, soft, exudative [PSE] and acid, soft, exudative [ASE]).

\section{MATERIAL AND METHODS}

The study was conducted on 114 porkers which were crossbred sows and boars of Camborough 22, lines 337PIC (Pig Improvement Company, Hendersonville, TN, USA) (C22×PIC), $\mathrm{N}=34$; Norsvin Landrace $(\mathrm{C} 22 \times \mathrm{NL}), \mathrm{N}=35$ and Pietrain $(\mathrm{C} 22 \times \mathrm{Pi})$, and $\mathrm{N}=45$. In each group, there were similar numbers of barrows and gilts sired by three boars. All the animals were provided with identical environmental and nutritional conditions.

After fattening, the animals were subjected to starvation for 20 hours. Next the animals were transported in special vehicles to a large industrial slaughter house located $40 \mathrm{~km}$ away. The slaughtering was conducted in accordance with standard veterinary and technological regulations and took place after 2 hours of lairage. Porkers were stunned using electrical current. Manual Lotterschmidt Weinberger tongs were used. The porkers were bled in a horizontal position.

The porkers were weighed before being slaughtered. After slaughter, the ULTRA-FOM 300 apparatus was used to estimate meatiness in the longissimus lumborum ( $\mathrm{mll}$ ) muscle of the warm carcasses. The meat quality of the hanging carcasses was assessed in the $\mathrm{mll}$, at the level of the last thoracic vertebra. The estimation of meat quality was based on the measurements of its $\mathrm{pH}\left(\mathrm{pH}_{45}\right.$, and $\left.\mathrm{pH}_{24 \mathrm{~h}}\right)$, electrical conductivity $\left(\mathrm{EC}_{90}\right.$, and $\left.\mathrm{EC}_{24 \mathrm{~h}}\right)$, lightness $\left(\mathrm{L}^{*}\right)$, and thermal drip and water holding capacity. Meat $\mathrm{pH}$, electrical conductivity, and lightness were determined using the Handylab 2 (Schott Geräte, Meinz, Germany) apparatus with a glass and calomel electrode, LF-STAR (Matthäus, Nobitz, Germany) apparatus, and Minolta 508i spectrophometer, respectively. Thermal drip was calculated as the difference in the meat sample weight before and after heating in a water bath at $85^{\circ} \mathrm{C}$ for $10 \mathrm{~min}$.

Water holding capacity measured as free water content (\%) was determined with Grau and Hamm's method (1952) modified by Pohija and Niinivaara (1957).

Meat quality was determined in accordance with the method described by Borzuta and Pospiech (1999), with particular focus on the following parameters:

$$
\begin{aligned}
& \mathrm{RFN} \mathrm{pH}_{45},>5.8 ; \mathrm{EC}_{90},<8 \mathrm{mS} / \mathrm{cm} ; \mathrm{EC}_{24 \mathrm{~h}}<8 \mathrm{mS} / \mathrm{cm} \\
& \text { PSE } \mathrm{pH}_{45}, \leq 5.8 ; \mathrm{EC}_{90}, \geq 8 \mathrm{mS} / \mathrm{cm} ; \mathrm{EC}_{24 \mathrm{~h}} 8 \geq \mathrm{mS} / \mathrm{cm} \\
& \text { ASE } \mathrm{pH}_{45},>5.8 ; \mathrm{EC}_{90},<8 \mathrm{mS} / \mathrm{cm} ; \mathrm{EC}_{24 \mathrm{~h}} \geq 8 \mathrm{mS} / \mathrm{cm} .
\end{aligned}
$$

Polymorphism in locus $R Y R l$ was established using the PCR-RLFP (polymerase chain reaction-restriction fragment length polymorphism) method (Fujii et al., 1991). The biological material comprised porcine blood. Isolation of DNA from blood leukocytes was based on methodology provided by Kawasaki (1990) and modified by Coppieters et al. (1992). An Engine MJ Research (PTC-200 Peltier Thermal Cycler, Ramsey, MN, USA) thermocycler was used to perform the PCR amplication.

For the purpose of the analyses, the crossbred porkers were divided into two weight groups: 100 to $115 \mathrm{~kg}$ (light porkers) and 116 to $130 \mathrm{~kg}$ (heavy porkers).

\section{Statistical methods}

The obtained results were statistically verified using the SAS v. 9.2 (2011) statistical package. Basic statistical parameters were determined with the MEANS-SAS v. 9.2. (2011) procedure.

In the first analysis (Tables 1, 2, and 3), the significance of the experimental factors (breed, sex, slaughter weight, warm carcass weight, post-slaughter meatiness) was

\begin{tabular}{|c|c|c|c|c|c|}
\hline \multirow{2}{*}{ Item } & \multicolumn{3}{|c|}{ Fixed effects } & \multicolumn{2}{|c|}{ Regression effects $\beta$} \\
\hline & Breed & Sex & Slaughter weight & Hot carcass weight & Meatiness \\
\hline Slaughter weight $(\mathrm{kg})$ & $* *$ & NS & - & $* *$ & NS \\
\hline Hot carcass weight $(\mathrm{kg})$ & $* *$ & NS & $* *$ & - & NS \\
\hline Meatiness (\%) & NS & $* *$ & NS & NS & - \\
\hline $\mathrm{pH}_{45^{\prime}}$ & NS & NS & NS & NS & NS \\
\hline $\mathrm{pH}_{24}$ & $*$ & $*$ & NS & $* *$ & NS \\
\hline $\mathrm{EC}_{90^{\prime}}(\mathrm{mS} / \mathrm{cm})$ & NS & NS & NS & NS & NS \\
\hline $\mathrm{EC}_{24 \mathrm{~h}}(\mathrm{mS} / \mathrm{cm})$ & NS & NS & NS & NS & NS \\
\hline Lightness (L*) & $* *$ & NS & NS & NS & NS \\
\hline Cooking loss $(\%)$ & NS & NS & NS & NS & NS \\
\hline WHC, free water content (\%) & $* *$ & NS & NS & NS & NS \\
\hline
\end{tabular}
determined with a multifactorial/multivariate analysis of

Table 1. Evaluation of the influence of experimental factors on the examined features

NS, not significantly; EC, electrical conductivity; WHC, water holding capacity.

** Statistical significance at $(\mathrm{p} \leq 0.01) ; *$ Statistical significance at $(\mathrm{p} \leq 0.05)$. 
Table 2. Selected meat quality parameters depending on animal breed

\begin{tabular}{|c|c|c|c|c|c|c|}
\hline \multirow{3}{*}{ Traits } & \multicolumn{6}{|c|}{ Breed } \\
\hline & \multicolumn{2}{|c|}{$\mathrm{C} 22 \times \mathrm{PIC}$} & \multicolumn{2}{|c|}{$\mathrm{C} 22 \times \mathrm{NL}$} & \multicolumn{2}{|c|}{$\mathrm{C} 22 \times \mathrm{Pi}$} \\
\hline & Mean & SD & Mean & SD & Mean & SD \\
\hline Slaughter weight (kg) & $118.69^{\mathrm{A}}$ & 8.13 & $115.97^{\mathrm{B}}$ & 7.15 & $113.69^{\mathrm{C}}$ & 5.60 \\
\hline Hot carcass weight $(\mathrm{kg})$ & $92.13^{\mathrm{A}}$ & 6.44 & $90.10^{\mathrm{B}}$ & 6.13 & $88.11^{\mathrm{C}}$ & 4.82 \\
\hline Meatiness (\%) & 56.98 & 3.66 & 56.97 & 2.52 & 55.79 & 3.02 \\
\hline $\mathrm{pH}_{45^{\prime}}$ & 6.09 & 0.26 & 6.19 & 0.31 & 6.04 & 0.26 \\
\hline $\mathrm{pH}_{24}$ & $5.54^{\mathrm{a}}$ & 0.04 & $5.57^{\mathrm{b}}$ & 0.08 & $5.53^{\mathrm{a}}$ & 0.08 \\
\hline $\mathrm{EC}_{90^{\prime}}(\mathrm{mS} / \mathrm{cm})$ & 5.24 & 2.50 & 4.68 & 2.41 & 4.77 & 2.32 \\
\hline $\mathrm{EC}_{24 \mathrm{~h}}(\mathrm{mS} / \mathrm{cm})$ & 5.63 & 2.62 & 5.47 & 2.66 & 5.19 & 2.22 \\
\hline Lightness $\left(\mathrm{L}^{*}\right)$ & $56.99^{\mathrm{A}}$ & 3.23 & $54.85^{\mathrm{B}}$ & 1.96 & $57.40^{\mathrm{A}}$ & 2.79 \\
\hline Cooking loss $(\%)$ & 27.20 & 1.65 & 27.09 & 2.38 & 27.64 & 1.86 \\
\hline WHC, free water content (\%) & $36.88^{\mathrm{A}}$ & 2.29 & $34.89^{\mathrm{B}}$ & 1.95 & $36.49^{\mathrm{A}}$ & 2.13 \\
\hline
\end{tabular}

C22, Camborough; PIC, Line 337; NL, Norsvin Landrace; Pi, Pietrain; SD, standard deviation; EC, electrical conductivity; WHC, water holding capacity.

${ }^{A-C}$ Statistical significance at $(\mathrm{p} \leq 0.01) ;{ }^{\text {a-c }}$ Statistical significance at $(\mathrm{p} \leq 0.05)$.

covariance using the GLM-SAS v. 9.2. (2011) procedure, according to the following linear model:

$$
y_{i j k l}=\mu+g_{i}+s j+s w_{k}+\beta_{1} c w_{i j k l}+\beta_{2} m t_{i j k l}+e_{i j k l}
$$

$y_{i j k l}$, value of the analysed trait;

$\mu$, total mean;

$g_{i}$, animal breed fixed effect $(\mathrm{i}=1,2,3)$;

${ }_{s j}$, sex of the animal $(j=1,2)$;

$s w_{k}$, slaughter weight in the group $(\mathrm{k}=1,2)$;

$\beta_{1}, \beta_{2}$, partial regression coefficients;

$c w_{i j k l}$, weight of warm carcass;

$m t_{i j k l}$, post-slaughter carcass meatiness;

$e_{i j k l}$, random error;

In the second analysis (Table 4), breed groups were divided into two weight groups; the $100 \mathrm{~kg}$ to $115 \mathrm{~kg}$ slaughter weight group and the $116 \mathrm{~kg}$ to $130 \mathrm{~kg}$ group.

To thoroughly compare the means for a given item, a

Table 3. Selected meat quality parameters depending on slaughter weight of animals

\begin{tabular}{|c|c|c|c|c|}
\hline \multirow{3}{*}{ Traits } & \multicolumn{4}{|c|}{ Slaughter weight $(\mathrm{kg})$} \\
\hline & \multicolumn{2}{|c|}{100 to 115} & \multicolumn{2}{|c|}{116 to 130} \\
\hline & Mean & SD & Mean & SD \\
\hline Slaughter weight $(\mathrm{kg})$ & $110.05^{\mathrm{A}}$ & 3.38 & $122.18^{\mathrm{B}}$ & 4.21 \\
\hline Hot carcass weight (kg) & $85.43^{\mathrm{A}}$ & 3.27 & $94.77^{\mathrm{B}}$ & 4.06 \\
\hline Meatiness (\%) & 56.53 & 2.87 & 56.49 & 3.41 \\
\hline $\mathrm{pH}_{45^{\prime}}$ & 6.12 & 0.25 & 6.09 & 0.31 \\
\hline $\mathrm{pH}_{24}$ & 5.54 & 0.06 & 5.55 & 0.09 \\
\hline $\mathrm{EC}_{90^{\prime}}(\mathrm{mS} / \mathrm{cm})$ & 4.63 & 2.04 & 5.17 & 2.72 \\
\hline $\mathrm{EC}_{24 \mathrm{~h}}(\mathrm{mS} / \mathrm{cm})$ & 5.22 & 2.28 & 5.61 & 2.66 \\
\hline Lightness $\left(\mathrm{L}^{*}\right)$ & 56.51 & 2.72 & 56.51 & 3.13 \\
\hline Cooking loss $(\%)$ & 27.61 & 1.88 & 27.06 & 2.05 \\
\hline WHC, free water content $(\%)$ & 36.19 & 2.25 & 36.05 & 2.30 \\
\hline
\end{tabular}

number of multiple comparisons were conducted using Duncan's new multiple range test and the T-test. Correlations between given factors (meat quality classes, genotype, pre-slaughter body weight) were determined using the contingency analysis procedure with Fisher's exact test and $\mathrm{V}_{\text {Cramer }}$ coefficient (proc FREQ- SAS v. 9.2., 2011).

\section{RESULTS AND DISCUSSION}

None of the examined porkers had the stress resistance gene $\left(R Y R I^{T}\right)$. The evaluation of the significance of experimental factors on the analysed meat qualitative features was presented in Table 1. The evaluation showed that breed affects several of the qualitative parameters of meat but sex only affects carcass meatiness and the final $\mathrm{pH}$ value of meat. Among the three analysed animal breeds, the $\mathrm{C} 22 \times \mathrm{NL}$ crossbred animals proved to have the highest $\mathrm{pH}_{24}$, lowest $\mathrm{L}^{*}$ value, and lowest free-water content $(\mathrm{p} \leq 0.05$; Table 2). The average weight of the slaughtered animals in the group of lighter porkers was $110 \mathrm{~kg}$, while in the group of heavier porkers it was $122 \mathrm{~kg}$. The same post-slaughter average meatiness of $56.5 \%$ was found in both groups. The analysis of the qualitative meat features, according to the weight group of the slaughtered animals, did not show any statistically significant differences ( $>>0.05$; Table 3$)$. The obtained low $\mathrm{pH}_{45}$, values indicated the fast course of glycogenolysis. These values were much lower than in the studies of other researchers (Czyżak-Runowska et al., 2005; Grześkowiak et al., 2009; Łyczyński et al., 2009; Edwards et al., 2010). In the slaughtered carcasses of porkers with higher body weights, we observed a tendency for lower free-water content, which was not statistically confirmed ( $\mathrm{p}$ $=0.6051$; Table 3). A higher free-water content was noticeable in the heavier carcasses of the C22×PIC crossbred animals $(37.01 \%)$ compared to the heavier 
Table 4. Selected meat quality parameters depending on breed and slaughter weight $(\mathrm{kg})$ of animals

\begin{tabular}{|c|c|c|c|c|c|c|c|c|c|c|c|c|}
\hline \multirow[t]{2}{*}{ Trait } & \multicolumn{2}{|c|}{$\begin{array}{c}\text { C22 } \times \text { PIC } \\
100 \text { to } 115\end{array}$} & \multicolumn{2}{|c|}{$\begin{array}{l}\text { C22×PIC } \\
116 \text { to } 130\end{array}$} & \multicolumn{2}{|c|}{$\begin{array}{l}\mathrm{C} 22 \times \mathrm{NL} \\
100 \text { to } 115\end{array}$} & \multicolumn{2}{|c|}{$\begin{array}{l}\mathrm{C} 22 \times \mathrm{NL} \\
116 \text { to } 130\end{array}$} & \multicolumn{2}{|c|}{$\begin{array}{c}\mathrm{C} 22 \times \mathrm{Pi} \\
100 \text { to } 115\end{array}$} & \multicolumn{2}{|c|}{$\begin{array}{c}\mathrm{C} 22 \times \mathrm{Pi} \\
116 \text { to } 130\end{array}$} \\
\hline & Mean & SD & Mean & SD & Mean & SD & Mean & SD & Mean & SD & Mean & $\mathrm{SD}$ \\
\hline Slaughter weight $(\mathrm{kg})$ & 108.00 & 4.35 & 122.96 & 4.48 & 110.06 & 3.93 & 121.88 & 3.95 & 110.69 & 2.48 & 121.08 & 4.01 \\
\hline Hot carcass weight $(\mathrm{kg})$ & 84.30 & 3.85 & 95.26 & 4.18 & 85.40 & 3.69 & 94.81 & 4.10 & 85.81 & 2.86 & 93.79 & 3.89 \\
\hline Meatiness (\%) & 56.92 & 3.25 & 57.00 & 3.87 & 57.08 & 1.95 & 56.85 & 3.04 & 56.11 & 3.15 & 55.02 & 2.61 \\
\hline $\mathrm{pH}_{45^{\prime}}$ & 6.14 & 0.13 & 6.07 & 0.30 & 6.20 & 0.28 & 6.19 & 0.34 & 6.07 & 0.26 & 5.98 & 0.26 \\
\hline $\mathrm{pH}_{24}$ & 5.53 & 0.03 & 5.54 & 0.04 & 5.56 & 0.04 & 5.58 & 0.11 & 5.53 & 0.07 & 5.53 & 0.11 \\
\hline $\mathrm{EC}_{90^{\prime}}(\mathrm{mS} / \mathrm{cm})$ & 5.18 & 1.29 & 5.26 & 2.87 & 4.47 & 2.31 & 4.90 & 2.55 & 4.54 & 2.09 & 5.33 & 2.81 \\
\hline $\mathrm{EC}_{24 \mathrm{~h}}(\mathrm{mS} / \mathrm{cm})$ & 4.63 & 1.41 & 6.04 & 2.90 & 5.67 & 2.89 & 5.28 & 2.48 & 5.18 & 2.15 & 5.24 & 2.48 \\
\hline Lightness $\left(\mathrm{L}^{*}\right)$ & $56.32^{\mathrm{ab}}$ & 2.73 & $57.24^{\mathrm{b}}$ & 3.41 & $54.98 \mathrm{a}$ & 1.94 & $54.71 \mathrm{a}$ & 2.03 & $57.37 \mathrm{~b}$ & 2.78 & $57.49 \mathrm{~b}$ & 2.93 \\
\hline Cooking loss $(\%)$ & 26.89 & 1.40 & 27.32 & 1.75 & 27.48 & 2.22 & 26.69 & 2.53 & 27.88 & 1.79 & 27.05 & 2.00 \\
\hline WHC, free water content $(\%)$ & $36.54^{\mathrm{AB}}$ & 2.47 & $37.01^{\mathrm{A}}$ & 2.27 & $35.03^{\mathrm{ABb}}$ & 1.84 & $34.74^{\mathrm{Bb}}$ & 2.11 & $36.71^{\mathrm{ABa}}$ & 2.23 & $35.93^{\mathrm{AB}}$ & 1.82 \\
\hline
\end{tabular}

C22, Camborough; PIC, Line 337; NL, Norsvin Landrace; Pi, Pietrain; SD, standard deviation; EC, electrical conductivity; WHC, water holding capacity.

${ }^{\text {A-C }}$ Statistical significance at $(\mathrm{p} \leq 0.01) ;{ }^{\mathrm{a}-\mathrm{c}}$ Statistical significance at $(\mathrm{p} \leq 0.05)$.

carcasses of the C22×NL crossbred animals (34.74\%); ( $\leq \leq 0.05$; Table 4). As reported by Przybylski et al. (2012), a big drip loss significantly decreases the sensory value of meat.

The analysis of meat colour in our study showed that only the breed influenced meat lightness $\left(\mathrm{L}^{*}\right)$, and this was seen in those porkers with a slaughter weight of 100 to 115 $\mathrm{kg}\left(\mathrm{p} \leq 0.05\right.$; Table 4). Slaughter weight did not affect $\mathrm{L}^{*}$ values. Most authors report darker colour in heavier porkers compared to lighter porkers (Barowicz et al., 2006; Virgili et al., 2012).

The average values of all quality differentiators were within what is considered the normal meat category. Nonetheless, in our study, the qualitative analysis of the longissimus lumborum muscle of particular carcasses revealed the presence of defective meat. The defects in most cases were related to PSE meat but in some cases, acidic meat was observed. For that reason, further analyses included both defects (PSE and ASE). These two defects were then placed into one group - the defective meat group. Meat defects were observed in 20 carcasses, which means $17.54 \%$ of the investigated material.

Based on the distribution analysis of meat defects, a correlation was observed between the frequency of meat defects and the weight group of slaughtered animals within the entire analysed population $\left(\mathrm{p} \leq 0.05 ; \mathrm{V}_{\text {Cramera }}=0.25\right.$; Figure 1). The qualitative classification showed a meat defect frequency that was three times higher in the material obtained from carcasses of heavier porkers as opposed to the lighter ones, (respectively $8.47 \%$ and $27.27 \%$ ). It can be assumed that slaughtered porkers of higher body weight are less resistant to the stress related to slaughtering, and in particular, to stunning. During stunning, the electric current parameters should be individually adjusted to the body

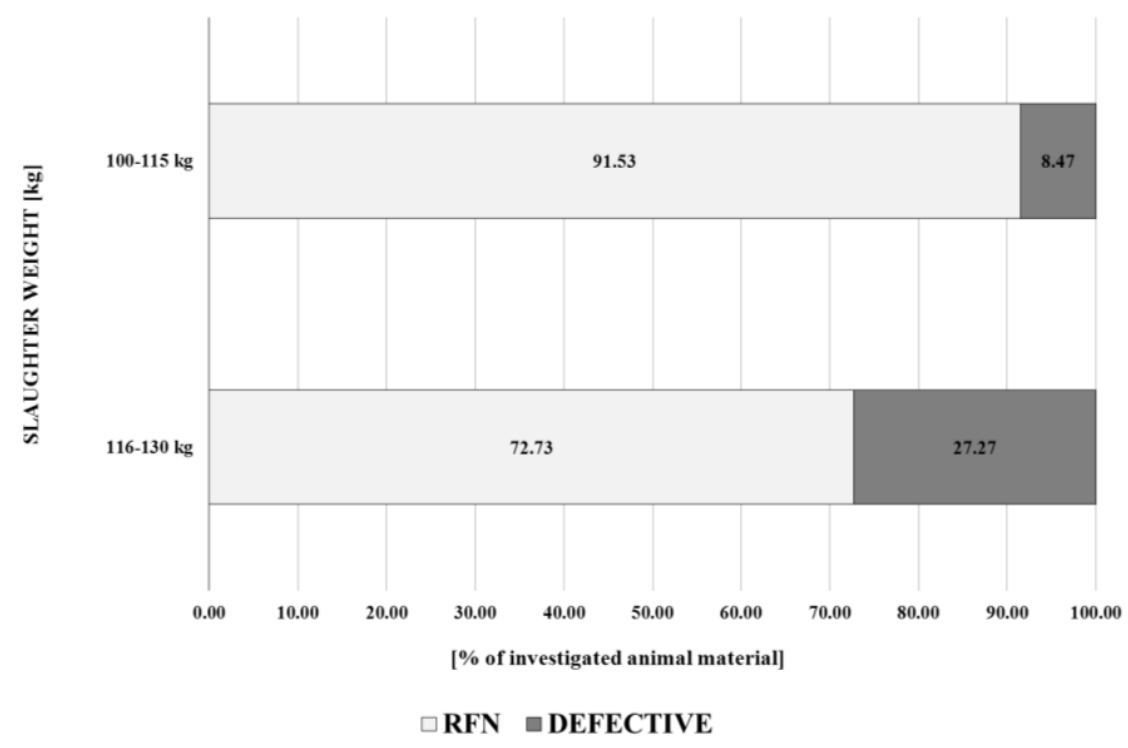

Figure 1. Frequency of occurrence of RFN meat and defective meat (PSE and ASE) depending on slaughter weight of animals. RFN, red, firm, non-exudative; PSE, pale, soft, exudative ; ASE, acid, soft, exudative. 


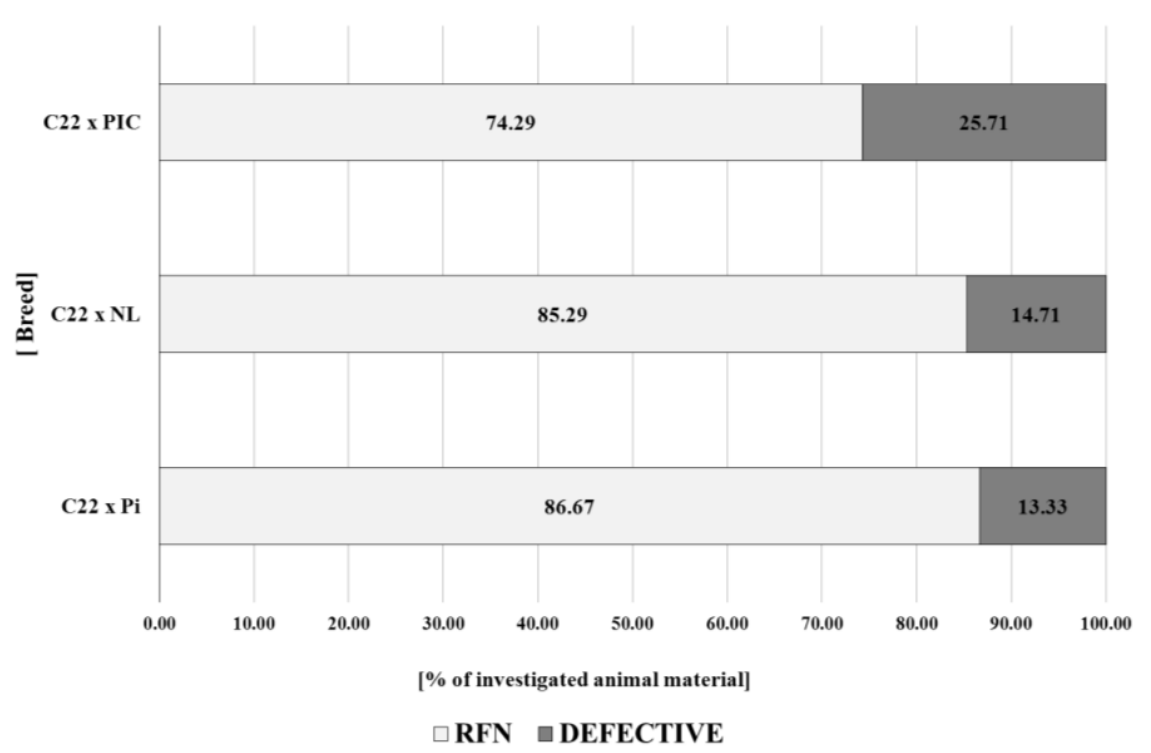

Figure 2. Frequency of occurrence of RFN meat and defective meat (PSE and ASE) depending on the breed. RFN, red, firm, nonexudative; PSE, pale, soft, exudative ; ASE, acid, soft, exudative.

weight of a given animal. The literature shows that an undeniably better meat quality is achieved when using the $\mathrm{CO}_{2}$ stunning system than when electrical stunning is used, irrespective of the type of electrode applied, stun duration or level of current used (Velarde et al., 2000; Heather et al., 2003). Moreover, the design of slaughter handling systems and the slaughtering procedures can have an effect on the meat quality (Faucitano et al., 1998).

No significant influence of breeds ( $p>0.05$; Figure 2$)$ and breed and slaughter-weight ( $>0.05$; Figure 3 ) on the occurrence of meat defects was observed.

Pospiech et al. (1983) reached similar conclusions in their studies. They evaluated the quality of meat derived from pigs slaughtered at different body weights: 90, 100,
110,120 , and $130 \mathrm{~kg}$. The mentioned authors discovered most meat defects in the groups of the lightest porkers slaughtered at the body weight of $90 \mathrm{~kg}$ as well as in the group of heavier ones slaughtered at $120 \mathrm{~kg}$. According to these authors, the differences in metabolism may have been related to changes in the nutrition levels of the animals. Similarly, Cisneros et al. (1996) observed that meat quality decreased with the increase in slaughter weight, which was manifested in an increased thermal drip. In crossbred porkers derived from the mating of boars (Pietrain $\times$ Large White) and sows (LandracexLarge White), the increase in slaughter weight from 116 to $133 \mathrm{~kg}$ did not positively influence meat quality (Latorre et al., 2004). In the research conducted by Barowicz et al. (2006), the increase in the

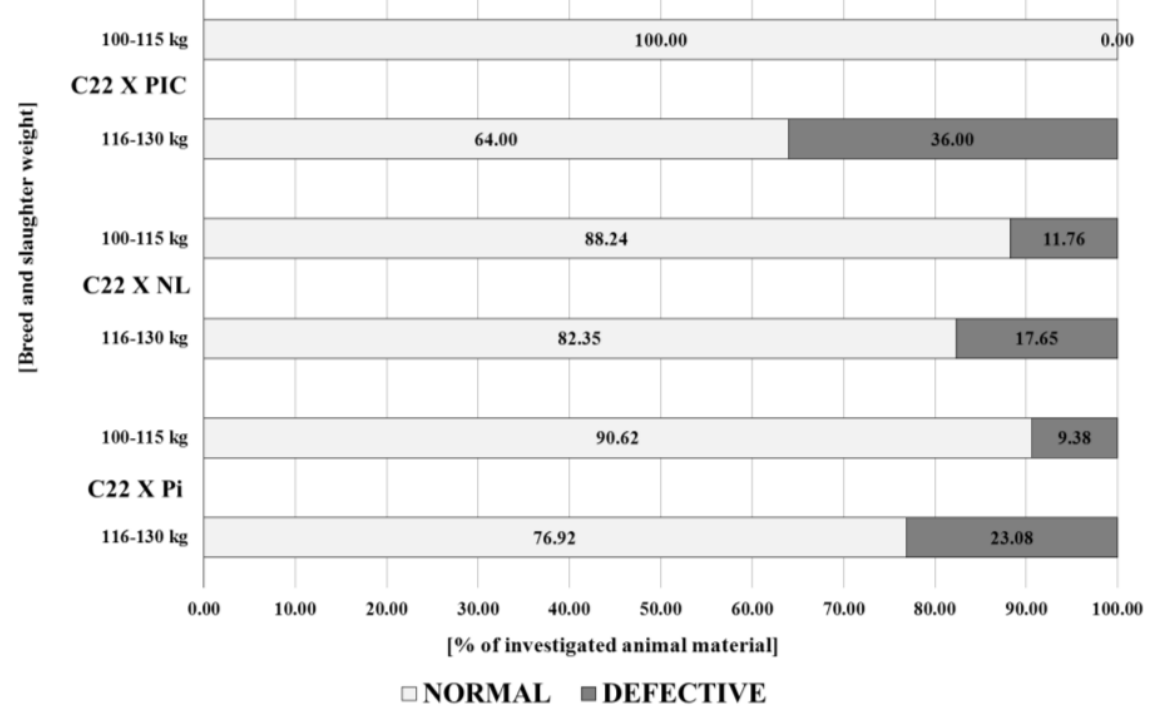

Figure 3. Frequency of occurrence of RFN meat and defective meat (PSE and ASE) depending on breed and slaughter weight of animals. RFN, red, firm, non-exudative; PSE, pale, soft, exudative ; ASE, acid, soft, exudative. 
slaughter weight from $101 \mathrm{~kg}$ to $129 \mathrm{~kg}$ caused a significant darkening in the meat and the meat had a less pleasant scent. Numerous researchers report that heavier animals are characterised by better quality meat with fewer defects. These results were confirmed by the studies of Łyczyński et al. (2006a). They observed lower levels (17.1\%) of defects in PSE and ASE meat. These levels were noted in heavier carcasses whose muscle tissue was characterised by a higher content of intramascular fat compared to lighter carcasses of lower intramascular fat content (25.7\%). Similarly, the studies of Beattie et al. (1999) showed that meat quality can be improved when the carcass weight is from 70 to $100 \mathrm{~kg}$. Also Correa et al. (2006) showed that porkers can be slaughtered at higher body weights of 107 to $125 \mathrm{~kg}$ without deterioration of carcass and meat quality. Also Strzelecki et al. (2007), in contrast to our study, showed that the slaughter weight of porkers at $133 \mathrm{~kg}$, significantly improved the physicochemical and sensory parameters of meat and raw smoked tenderloin compared to porkers slaughtered at $114 \mathrm{~kg}$.

\section{CONCLUSION}

Based on our research and the research of other authors, we can conclude that the elimination of the $R Y R I^{T}$ gene in carcasses does not guarantee meat of good quality. It should be pointed out, that animals of high genetic potential must receive proper nutrition and care at all the production stages including breeding, fattening, handling before slaughter, slaughter, post-slaughter handling of carcasses, and meat distribution. In summary, the level of PSE and ASE meat with defects in the carcasses without the $R Y R I^{T}$ gene, amounted to $17.54 \%$. The conducted quality classification of longissimus lumborum muscle in different carcasses indicated that meat with defects occurs three times more often in the crossbred animals of higher body weight (116 to $130 \mathrm{~kg}$ ) than in crossbred animals slaughtered at lower body weights (100 to $115 \mathrm{~kg}$ ). Statistical analysis of meat quality parameters in different weight groups of the crossbred animals did not reveal any significant deterioration in quality. These results indicate the necessity of conducting individual quality evaluations of different carcasses.

\section{REFERENCES}

van Arendonk, J. A. M. 2011. Opportunities for animal breeding to meet the challenges of the future. Nauka Przyr. Technol. 5, 3, \#30.

Barowicz, T., M. Pietras, M. Pieszka, and W. Migdał. 2006. Evaluation of carcass and meat quality in Polish Landrace fatteners slaughtered at $128 \mathrm{~kg}$ live body weight. Anim. Sci. Pap. Rep. 24 (Suppl) 2:29-36.
Beattie, V. E., R. N. Weatherup, B. W. Moss, and N. Walker. 1999. The effect of increasing carcass weight of finishing boars and gilts on joint composition and meat quality. Meat Sci. 52:205211.

Borzuta, K., D. Lisiak, A. Borys, J. Strzelecki, F. Magda, E. Grześkowiak, and B. Lisiak. 2010. Study on the effect of lean meat content on commercial value of porcine carcasses (in Polish). Nauka Przyr. Technol. 4, 5, \#54.

Borzuta, K. and E. Pospiech. 1999. Analysis of benefits related to the increase of porker meatiness and losses caused by meat quality deterioration (in Polish). Gosp. Mięs. 9:36-40.

Coppieters, W., A. van Zeveren, A. van de Weghe, L. Peelman, and Y. Bouquet. 1992. Direct genotyping stress susceptibility and resistance in pigs by means of DNA test (in Dutch). Vlamms Diergeneeskunding Tijdschrift. 61:68-72.

Cisneros, F., M. Ellis, F. K. McKeith, J. McCaw, and R. L. Fernando. 1996. Influence of slaughter weight on growth and carcass characteristics, commercial cutting and curing yields, and meat quality of barrows and gilts from two genotypes. J. Anim. Sci. 74:925-933.

Correa, J. A., L. Faucitano, J. P. Laforest, J. Rivest, M. Marcoux, and C. Garièpy. 2006. Effects of slaughter weight on carcass composition and meat quality in pigs of two different growth rates. Meat Sci. 72:91-99.

Czyżak-Runowska, G., A. Łyczyński, E. Pospiech, E. Rzosińska, and M. Koćwin-Podsiadła. 2005. Rate of growth of porkers and selected fattening and slaughter traits and meat quality. Ann. Anim. Sci. 2:(Suppl):17-20.

Eblis M., F. K. McKeith, and K. D. Miller. 1999. The effects of genetic and nutritional factors on pork quality (A review). Asian Australas. J. Anim. Sci. 12:261-270.

Edwards, L. N., T. Grandin, T. E. Engle, M. J. Ritter, A. A. Sośnicki, B. A. Carlson, and D. B. Anderson. 2010. The effects of pre-slaughter pig management from the farm to the processing plant on pork quality. Meat Sci. 86:938-944.

Fàbrega, E., X. Manteca, J. Font, M. Gispert, D. Carriòn, A. Verlarde, J. L. Ruiz-Dela-Torre, and A. Diestyr. 2002. Effects of halothane gene and pre-slaughter treatment on meat quality and welfare from two pig crosses. Meat Sci. 62:463-472.

Fauciano, L., L. Marquardt, M. S. Oliveira, H. Sebastiany Coelho, and N. N. Terra. 1998. The effect of two handling and slaughter systems on skin damage, meat acidification and colour in pigs. Meat Sci. 50:13-19.

Fischer, K. 2007. Drip loss in pork: Influencing factors and relation to further meat quality traits. J. Anim. Breed. Genet. 124(Suppl):12-18.

Florowski, T., A. Pisula, and M. Kamyczek. 2007. Influence of high meatiness on pork quality from pigs free of $R Y R I^{T}$ gene (in Polish). Med. Wet. 63:326-329.

Fujii, J., K. Otsu, F. Zorzato, S. De Leon, V. K. Khanna, J. E Weiler, P. O'Brien, and D. H. MacLennan. 1991. Identification of a mutation in porcine ryanodine receptor associated with malignant hyperthermia. Science 253:448-451.

Grau, R. and R. Hamm. 1952. A simple method for the determination of water absorption in the meat. (in German). Fleichwirtschaft 4:295-297.

Grześkowiak, E., A. Borys, K. Borzuta, J. T. Buczyński, and D. Lisiak. 2009. Slaughter value, meat quality and backfat fatty acid profile in Zlotnicka White and Zlotnicka Spotted fatteners. 
Anim. Sci. Pap. Rep. 27:115-125.

Heather, A. Channon, A. M. Payne, and R. D. Warner. 2003. Effect of stun duration and current level applied during head to back and head only electrical stunning of pigs on pork quality compared with pigs stunned with $\mathrm{CO}_{2}$. Meat Sci. 65:13251333.

Kawasaki, E. S. 1990. Sample preparation from blood cells and other fluids. In: PCR Protocols: a Guide to Methods and Applications (Eds. M. A. Innis, D. H. Gelfand, J. J. Sninsky, and T. J. White). Academic Press, Orlando, FL, USA. 146-152.

Koćwin-Podsiadła, M., A. Zybert, E. Krzęcio, K. Antosik, H. Sieczkowska, J. Kurył, and A. Łyczyński. 2002. The influence of hot carcass weight on lean meat content and its technological usefulness in crossbreds of Danish landrace with Duroc. Ann. Anim. Sci. 2:319-324.

Koćwin-Podsiadła, M., E. Krzęcio, and W. Przybylski. 2006. Pork quality and methods of its evaluation - A review. Pol. J. Food Nutr. Sci. 15/56:241-248.

Kortz, J., A. Rybarczyk, A. Pietruszka, R. Czarnecki, M. Jakubowska, and T. Karamucki. 2004. Effect of HAL genotype on normal and faulty meat frequency in hybrid fatteners. Pol. J. Food Nutr. Sci. 13/54:387-390.

Latorre, M. A., R. Lazaro, D. G Valencia, P. Medel, and G. G Mateos. 2004. The effects of gender and slaughter weight on the growth performance, carcass traits, and meat quality characteristics of heavy pigs. J. Anim. Sci. 82:526-533.

Leach, L. M., M. Ellis, D. S. Sutton, F. K Mc Keith, and E. R. Wilson. 1996. The growth performance, carcass characteristics, and meat quality of halothane carrier and negative pigs. J. Anim. Sci. 74:934-943.

Lee, Y. B. and Y. I. Choi. 1999. PSE (pale, soft, exudative) Pork : The Causes and Solutions (A review). Asian Australas. J. Anim. Sci. 12:244-252.

Łyczyński, A., S. Wajda, G. Czyżak-Runowska, E. Rzosińska, and B. Grześ. 2006. Effect on environmental condition on pork meat quality. Pol. J. Food Nutr. Sci. 15/56:109-116.

Łyczyński, A., E. Pospiech, E. Rzosińska, G. Czyżak-Runowska, B. Grześ, B. Mikołajczak, and E. Iwańska. 2006a. Quality of porcine meat in relation to pig genotype and intramuscular fat content. Anim. Sci. Pap. Rep. 24(Suppl 2): 195-204.

Łyczyński, A., G. Runowska, E. Pospiech, M. Koćwin-Podsiadła, J. Wojtczak, E. Rzosińska, B. Grześ, B. Mikołajczak, and E. Iwańska. 2009. Estimation of selected porcine meat quality indicators on the basis of electrical conductivity measured 24 hours post-slaughter. Anim. Sci. Pap. Rep. 27:51-58.

Martin, A. H., A. P. Sather, H. T. Fredeen, and R. W. Jolly. 1980. Alternative market weights for swine. II Carcass composition and meat quality. J. Anim. Sci. 50:699-705.
Migdał, W., P. Paściak, A. Gardzińska, T. Barowicz, M. Pieszka, and D. Wojtysiak. 2004. The effect of genetic and environmental factors on the quality of pork (in Polish). Prace i Mater. Zoot. Special Issue. 15:103-117.

Monin, G., C. Larzul, P. Le Roy, J. Culioli, C. Touraille, and P. Sellier. 1999. Effect of halothane genotype and slaughter weight on texture of pork. J. Anim. Sci. 77:408-415

Pohia, N. S. and F. P. Ninivaara. 1957. The determination of water holding capacity of meat using constant pressure method. (in German). Fleischwirtschaft 9:193-195.

Pospiech, E., B. Dzierżyńska-Cybulko, L. Gustowska, W. Maruniewicz, and W. Darul. 1983. The influence of slaughter weight of pigs on the meat quality (in German). Fleischwirtschaft 63:1072-1075.

Pospiech, E., K. Borzuta, A. Łyczyński, and W. Płókarz. 1998. Meat defects and their economic importance. Pol. J. Food Nutr. Sci. 7/48:7-20.

Przybylski, W., S. Niemyjski, E. Pospiech, E. Rzosińska, and G. Czyżak-Runowska. 2005. Evaluation of possibilities production of heavy pigs with high percentage of meat in carcass originated from selected genetic group (in Polish). Roczniki Instytutu Przemysłu Mięsnego i Tłuszczowego Papers of the Meat and Fat Research Institute in Warsaw. 42/43:7-15.

Przybylski, W., D. Jaworska, K. Boruszewska, M. Borejko, and W. Podsiadły. 2012. Technological and sensory quality of defective pork meat (in Polish). Żywność. Nauka. Technologia. Jakość - Food. Sci. Technol. Qual. 1:116-127.

Rosenvold, K. and H. J. Andersen. 2003. Factors of significance for pork quality - A review. Meat Sci. 64:219-237.

Strzelecki, J., E. Grześkowiak, K. Borzuta, A. Borys, D. Lisiak, and P. Janiszewski. 2007. Weight impact of the PEN-AR-LAN line fatteners on the slaughter value and meat quality. Pol. J. Food Nutr. Sci. 57:511-515.

Velarde, A., M. Gispert, L. Faucitano, X. Manteca, and A. Diestre. 2000. The effect of stunning method on the incidence of PSE meat and haemorrhages in pork carcasses. Meat Sci. 55:309314

Virgili, R., M. Degni, C. Schivazappa, V. Faeti, E. Poletti, G. Marchetto, M. T. Pacchioli, and A. Mordenti. 2003. Effect of age at slaughter on carcass traits and meat quality of Italian heavy pigs. J. Anim. Sci. 81:2448-2456.

Zybert, A., M. Koćwin-Podsiadła, E. Krzęcio, H. Sieczkowska, and K. Antosik. 2005. The gain and per cent content of primal cuts from the cutting of carcasses differentiated by hot carcass weight and leanness class according to the 'EUROP' carcass grading system (in Polish). Żywność. Nauka. Technologia. Jakość- Food. Sci. Technol. Qual. 3:221-223. 